Ciuca, V.M. (2021). Pages of legal and moral ethnography in the work of the Bukovina Polymath founder Simeon Floria Marian, a Romanian souls' columnist on the threshold of the Great Unification: his outstanding contribution to the ideal millennium fulfillment. The Law and its Interpretation. Collection of Scientific Articles. European Scientific e-Journal, 5 (11), 7-36. Hlučín-Bobrovníky: "Anisiia Tomanek" OSVČ. (in Romanian)

Ciucă, V.M. (2021). Pagini de etnografie juridico-morală în opera fondatoare a bucovineanului polimat Simeon Florea Marian, cronicar al sufletelor româneşti în pragul Marii Uniri: Remarcabila lui contribuție la înfăptuirea milenarului ideal. The Law and its Interpretation. Collection of Scientific Articles. European Scientific eJournal, 5 (11), 7-36. Hlučín-Bobrovníky: “Anisiia Tomanek” OSVČ.

DOI: $10.47451 /$ jur2021-03-002

EOI: $10.11244 /$ jur2021-03-002

The paper is published in Crossref, Internet Archive, Google Scholar, Academic Resource Index ResearchBib, JGate, ISI, CiteFactor, ICI, eLibrary databases.

Valerius M. Ciuca

Professor, Doctor of Jurisprudence

Faculty of Jurisprudence

Alexandru Ioan Cuza University

Iasi, Romania

E-mail : valerius.m.ciuca@gmail.com

\title{
Pages of legal and moral ethnography in the work of the Bukovina Polymath founder Simeon Floria Marian, a Romanian souls' columnist on the threshold of the Great Unification: his outstanding contribution to the ideal millennium fulfillment
}

\section{Abstract:}

In this manner, synthesis and analysis thesis from the fragile explored field of legal ethnology, thesis "anchored in symbolic ports", such as The Royal House of Romania (King as synecdoche of Justice), such as the royal city Iaşi (Romanian normative and judicial traditions), or the municipalities Alba Iulia ('the bow and arow' in a 'centennial' socio-legal 'iconography'), Chişinău, Galați and Târgu Mureş. Missing from this painting is the supreme symbol of historical Bucovina, Suceava, the Citadel of Moldova, which, through it's polyhistor, Simeon Florea Marian (in his capacity recognized as "the first esthetician of the fairy tale, of this species of popular epic") contributed decisively to the resurgence of the moldavian and romanian legal-moral spirit. Today, in this voivodal framework of Suceava, I live the feeling of the closed circle, with meanings that go beyond the frontiers of simple thematic conferences. Sapiential and customary literature, popular, folkloric, oral, on Simeon Florea Marian, this venerable polyhistor of romanian culture has crystallized-forever in written and hermeneutic form marked by scientific precision, they are a fertile ground and worthy of being exploited noetically and for today's young jurists, more dedicated to jusnaturalism, perennial legal values, principles and morality, than the positive generation of ultra-formalists, legal, bordered by uncomfortable expressions of norms endowed only with text, not meaning, in the most rigid and kelsenian way with possibility. Without being an exhaustive demonstration, but only an invitation, among others, to discover the 
sapiential-legal values and the jusnaturalist - moralizing, spiritual one, of the romanian popular creations, in the wider, european concert, the same thesis with apoftegmatic 'dams', sapientogene, the present paper could only play the role of palladium, as a catalyst for possible intellectual burns in the legal field.

Keywords:

Simeon Florea Marian, legal and moral ethnography, Bukovina Polymath.

Valerius M. Ciucă

Professor, Doctor in drept

Facultatea de Drept

Universitatea „Alexandru Ioan Cuza”

Iaşi, România

E-mail : valerius.m.ciuca@gmail.com

\section{Pagini de etnografie juridico-morală în opera fondatoare a bucovineanului polimat Simeon Florea Marian, cronicar al sufletelor româneşti în pragul Marii Uniri: Remarcabila lui contribuţie la înfăptuirea milenarului ideal}

Pagini de etnografie juridico-morală în opera fondatoare a bucovineanului polimat Simeon Florea

Marian, cronicar al sufletelor româneşti în pragul Marii Uniri. Remarcabila lui contribuție la înfăptuirea milenarului ideal, Cluj-Napoca, in curs de apariție

\section{Adnotare:}

In acest fel, lucrări de sinteză şi de analiză din domeniul firav explorat al etnologiei juridice, lucrări "ancorate în porturi" simbolice, precum Casa Regală a României (Regele ca sinecdocă a Justiției), precum oraşul regal Iaşi (Tradiţii normative şi judiciare romanesti), sau municipiile Alba Iulia ("Arcul şi săgeata" într-o "iconografie" socio-juridică centenară"), Chişinău, Galați şi Târgu Mureş. Lipsea, din acest tablou, simbolul suprem al Bucovinei istorice, Suceava, Cetatea de Scaun a Moldovei, care, prin al ei polihistor, Simeon Florea Marian (în calitatea-i recunoscută de "prim estetician al basmului, al acestei specii a epicii populare", a contribuit decisiv la resurgența spiritului juridico-moral moldovenesc şi românesc. Astăzi, în acest cadru voevodal sucevean, trăiesc sentimentul cercului închis, cu semnificații ce depăşesc fruntariile simplelor conferințe tematice. Literatura sapiențială şi consuetudinară, populară, folclorică, orală, pe Simeon Florea Marian, acest venerabil polihistor al culturii româneşti a cristalizat-o pentru totdeauna în forme scriptice şi hermeneutice marcate de precizie ştiințifică, reprezintă un teren fertil şi demn de-a fi exploatat noetic şi pentru tinerii jurişti de astăzi, mai dedicați jusnaturalismului, valorilor juridice perene, principiilor şi moralității, decât generația pozitiviştilor ultraformalişti, legalişti, mărginiți de expresiile inconfortabile ale normelor dotate doar cu text, nu şi cu sens, în cel mai rigid şi kelsenian mod cu putință. Fără a fi o demonstrație exhaustivă, ci doar o invitație, printre altele, la descoperirea valorii sapiențial-juridice şi a celei jusnaturalistmoralizatoare, spirituale, a creațiilor populare româneşti, în concertul mai larg, european, acela al 
lucrărilor cu "îndiguiri" apoftegmatice, sapientogene, prezenta lucrare ar putea juca doar rolul de paladium, de catalizator pentru eventuale combustii intelectuale pe teren juridic.

\section{Cuvinte cheie:}

Simeon Florea Marian, etnografie juridico-morală, bucovineanului polimat.

\section{Motto: Principes mortales, res publica aeterna}

(Tacitus, 2017)

\section{Introducere}

În cursul Anului Centenar, anul de grație 2018, am încercat să reproduc secvențe ale gândirii socio-juridice româneşti concordante spiritului european al timpului pentru a ilustra, fie şi parțial, propensiunea acestui spirit față de valorile juridico-morale actuale europene. S-au adunat, în acest fel, lucrări de sinteză şi de analiză din domeniul firav explorat al etnologiei juridice, lucrări "ancorate în porturi" simbolice, precum Casa Regală a României (Regele ca sinecdocă a Justiției), precum oraşul regal Iaşi (Tradiţii normative şi judiciare romanesti), sau municipiile Alba Iulia ("Arcul şi săgeata" într-o "iconografie" socio-juridică centenară") [1], Chişinău (Suport scriptic al comunicării) [2], Galați [3] şi Târgu Mureş (Ciucă, 2017; Virtuți şi vicii într-un libellus diffamatorius, 2017). Lipsea, din acest tablou, simbolul suprem al Bucovinei istorice, Suceava, Cetatea de Scaun a Moldovei, care, prin al ei polihistor, Simeon Florea Marian (în calitatea-i recunoscută de "prim estetician al basmului, al acestei specii a epicii populare" (Olteanu, 2000) româneşti), a contribuit decisiv la resurgența spiritului juridico-moral moldovenesc şi românesc. Astăzi, în acest cadru voevodal sucevean, trăiesc sentimentul cercului închis, cu semnificații ce depăşesc fruntariile simplelor conferințe tematice.

Sentimentul de cucernică plecăciune față de ilustrul nostru înaintaş este dublat de acela de gratitudine pentru un spiritus loci inconfundabil ce-a ghidat primii mei paşi ezitanți în cariera de jurist şi de intelectual devotat cetății, spiritul acestui oraş care, în anii uceniciei mele de judecător, ocupa avanscena valorii benefice a gândirii juridice româneşti prin nume de rezonanţă, precum cele ale acestor judecători: Mihail. C. Ardeleanu, Paul Manoliu, Constantin Pojoga, Mircea Hâncu, Pavel Perju, Aurelian Târniceriu ş.a., pe care i-am evocat în propriu-mi forum internum, şi nu numai, ori de câte ori aveam nevoie de argumente vivante în privința valorilor juridice pe care le-am susținut [4]. 
Vă întrebați, probabil, de ce, în aces conclav al juriştilor, evocăm opera unui preot, teolog, istoric, prim etnograf dedicat modelului inductiv, al etnografiei aplicate [5], şi polimat român. În primul rând, pentru faptul dovedit că el a dorit să facă pate din această castă particulară a noastră, a juriştilor. Apoi, pentru motivul esențial al scoaterii la supafaţă a propensiunilor românilor din toate ținuturile lor istorice către drept, justiție şi moralitate, folosind stilul literar fabulatoriu şi subtilităţile metaforei, nelăsând să piară comori ale sufletului şi ale creativității poporului român şi răspunzând, astfel, comandamentului romantic herderian [6].

\section{Notițe bio-bibliografice [7]}

Simeon Florea Marian s-a născut la data de 1 septembrie 1847 la Ilişeştii Sucevei, părinţi fiindu-i Grigore şi Ruxanda Marian. Şase ani mai târziu, la 12 octombrie 1853, avea să se nască, la Şipotele Sucevei, județul Rădăuți, un alt bucovinean de seamă, Ciprian Porumbescu, fiul lui Iraclie şi al Emiliei Porumbescu. Un prim numitor comun al lor este comuna Ilişeşti, unde ambii au copilărit şi au studiat în clasele primare aproape concomitent, sub îndrumarea aceluiaşi învăţător de mare vocație, Dimitrie Cernăuțean, la aşa-numita Şcoală trivială (populară) română, afiliată Bisericii parohiale prin grija preotului Dimitrie Bucevschi (Brădățan, 2007) [8]. De acolo, ambii aveau să plece curând şi să-şi continue studiile în urbea Sucevei, Ciprian Porumbescu la Liceul de băieți, Griechisch-orientalisches Obergymnasium) ce fusese recent edificat, în 1860, iar Simeon Florea Marian, la Hauptschule (edificiul de astăzi este sediul Muzeului de Ştiințe ale Naturii din centrul municipiului).

În anul 1868, pe când Simeon avea 19 ani, un sătean din Ilişeşti îi ucide mişeleşte tatăl, dintr-o pricină de pământ. Tatăl lui era caracterizat ca "Grigoraş al popii, gospodar de frunte al satului, om harnic, foarte ordonat şi luminat, printre puţinii care şi-au trimis copiii la învăţătură (v. Gherasim Buliga)" [9]. "La înmormântare au fost şi mulţi colegi ai elevului Marian, s-au adunat şi oameni din împrejurimi, iar oficierea slujbei a făcut-o tatăl lui Ciprian Porumbescu, Iraclie, paroh în Stupca" [10]. În acest fel, Simeon devine "stâlpul de sprijin" al familiei întregi. O soartă asemănătoare a avut-o, în această privinţă, un alt tânăr de seamă al neamului nostru, Alexandru Papiu Ilarian, al cărui tată, preotul greco-catolic Ioan Pop, din Budiu de Câmpie, jud. Mureş (azi, eponim al marii personalităţi paşoptiste şi unioniste, Alexandru Papiu Ilarian) a fost ucis. În acest caz din urmă, asasinii şi vinovaţii moral erau adversarii, inamicii răzbunători şi sanghinari ai tânărului nostru revoluționar. 
După absolvirea clasei a VII-a de liceu, ca elev privatist (f.f.) la Năsăud, unde s-a refugiat din pricina comportamentului scandalos, abominabil, al românofobului Franz Theil, poreclit Scarabeus, directorul şcolii capitale Hauptschule din Suceava (Loghin, 1996) [11], diploma sau certificatul de maturitatea (Testimonium maturitatis) avea s-o obțină la Beiuş, oraş transilvănean cu largi reverberații unioniste, oraş ce-mi aminteşte şi de maestrul meu spiritual, prof. dr. doc. Marţian Cotrău [12], născut în Fizişul Bihorului, dar care-a studiat şi la Liceul "Vasile Vulcan" din Beiuş, stând la Internatul Paulian al călugărilor asumpţionişti [13]. Precum Simeon Florea Marian, şi profesorul Cotrău (ce avea să ispăşească mult în temnițele comuniste...) ar fi dorit să urmeze studii juridice, dar, în cazul ambilor, condițiile materiale s-au împotrivit. În Transilvania, "i-a cunoscut pe tribunii Axente Sever şi Simeon Balint, dar nu a reuşit să-l cunoască pe Avram Iancu, eroul căruia i-a închinat culegerea de Poezii poporane despre Avram Iancu (1900)" [11, p. 9]

Desăvârşirea studiilor se petrece la Cernăuți, la Facultatea de Teologie, iar din al treilea deceniu de viaţă, în tânărul preot polihistor şi savant se trezesc etnograful (fondatorul etnografiei româneşti), poetul, profesorul foarte bun pedagog, botanistul şi ornitologul, politologul literat ("sufletul" Revistei politice sucevene), istoricul şi umanistul salvator de patrimoniu cultural național.

În anul 1869, odată cu "debutul său editorial cu volumul Poesii poporale din Bucovina - Balade române culese şi corese" [9], publicat la Botoşani, creează, într-un grup de fodatori, Societatea Literară a Junimii Studioase, urmând, astfel, curentul de redeşteptare a conştiinței naţionale în rândul tinerilor, prin intermediul literaturii şi artei, după modelul deja consacrat în Principatele Române şi apoi în Regatul României, dar şi după modelul cenaclier foarte apreciat de Alexandru Papiu Ilarian, în Transilvania, mai ales, la Sibiu şi la Braşov (Societatea ASTR A, bunăoară). În cam acelaşi "vad" cultural, în anul 1887, Simeon Florea Marian "a fost printre fondatorii Clubului Român din Suceava, organizat după modelul Casinei Germane, unde se reuneau intelectualii grupați în jurul "Revistei politice", cu scopul "de-a întreține un cabinet de lectură şi a forma un centru de întâlnire şi petrecere pentru membrii săi", de a deschide "secțiuni pentru cultivarea cântării vocale şi instrumentale, cum şi a altor ramuri de petrecere socială, prelegeri literare şi conferințe ştiințifice.” (Brădăţan, 2017; Bumbac, 1906) Activitatea aceasta, precum şi participarea ca membru al Societăţii "Junimea" din Iaşi (1895), "România Jună” din Viena (1905), al Societăţii "Dacia" (1906), al Societăţii "Şcoala Română" din Suceava, etc. i-au atras 
duşmănii şi intrigi, cabale, ostilități din partea autorităților austriece [11, p. 9]. Acest model avea să se perpetueze şi-n Basarabia, chiar până la căderea comunismului.

Opera acestui dascăl (profesor de liceu la Gimnaziul Ortodox-Oriental (Nestor, 2000) [14]) este impresionantă [15], cu a sa capodoperă, "Trilogia vieții" (Naşterea la români, Nunta la români, Inmormântarea la români) (Marian, 1995), urmată de cele trei volume de Sărbători la români (Cârnilegile, Păresimile, Cincizecimea) (Marian, 2015), într-un cuvânt, patriotul care, în acest mod, a binemeritat titlul de academician în Academia Română. A meritat din plin după discursul său de recepție, intitulat Chromatica poporului român, laudele din discursul de răspuns, ce i-au fost adresate de marele enciclopedist român (urmaş natural al lui Dimitrie Cantemir şi simbolic reper, deschizător de drumuri pentru Mihai Eminescu [16], foarte ataşat, de altfel, de Suceava şi de istoria sa bogată şi nobilă, voevodală (Jucan, 1999) [17], dar şi pentru Mircea Eliade), nimeni altul decât Bogdan Petriceicu Haşdeu: "Aducându-te aici, Academia Română umple un gol ce se simțea în rândurile noastre. Avem istorici, naturalişti, filologi, matematicieni, economişti, poeți, publicişti, un buchet modest din câte s-au putut culege din tânăra grădină a neamului românesc, dar un etnograf în adevăratul sens al cuvântului, care să fi pătruns în toate unghiulețele, fie cât de ascunse, din traiul, din cugetul, din simțul poporului român, ne lipsea până acum. Acest etnograf, dă-mi voie a ți-o spune, june şi distins coleg, singurul etnograf român, deocamdată, eşti tu." (Haşdeu, 1882) În sfârşit, a meritat cu prisosinţă onorurile, premiile şi aprecierile unanime ale contemporanilor săi, români şi străini (între care, strălucește distincția cu Ordinul "Coroana României", în grad de ofițer, cu "medalia jubiliară" acordate de Regele Carol I în anul 1904). De l-am fi putut colinda, în acele vremuri romantice, i-am fi transmis şi noi urarea de "Sănătate şi putere, pentru binele neamului nostru românesc şi pentru spiritul bun, european, preacuvioase părinte-profesor Simeon Florea Marian! Lerului Doamne, Ler!' (Cojocaru, 2001) [18].

Dintre multele scrieri cu caracter de necrolog, de orație funebră, după moartea sa din 1907, pe care un cercetător român, doamna Dr. Aura Brădățan le-a cules, ca parte esențială pentru pasiunea-i de-o viaţă şi anume salvarea memoriei acestui magnific polihistor, polimat, poligraf noi vom reține aici, cu rol pur simbolic, două:

- "Academia pierde un membru de frunte, iar neamul românesc nu numai un vrednic păstor şi apostol luminat al poporului, ci şi un cărturar şi scriitor iscusit, care şi-a închinat partea cea mai mare de viaţă înălţării naţionale.” (Preşedintele Academiei Române, Ioan Lazăr Kalinderu, 1907) 
- " Etnograful depune mare zel în a aduna tot ce se tipărise până la el, privitor la temele tratate, şi mai cu seamă menține un susţin contact cu foştii elevi, ajunşi unii din ei învăţători ori preoți în sat, cu prieteni din toate unghiurile ţării şi chiar cu cercetători de peste hotare. Suceava, în felul acesta, devine un centru de mare însuflețire ştiințifică, promovată de un singur om. Ceea ce astăzi fac institute cu zeci de cercetători, Marian, în condiții materiale foarte modeste, a realizat singur o operă grandioasă." (Vrabie, 1968)

Adaug la acestea, cuvintele cu valoare de ferpar sau, mai bine, de orație funebră, scrise de marele istoric Nicolae Iorga: "Şi să nu uităm încercarea lui (a lui S. F. Marian, n.m.) de a da Bucovinei o cetire culturală, în care să se amestece totuşi şi discuția realităților politice, să nu uităm "Revista politică" din Suceava, care a trăit mai puțină vreme de cum merita, şi cele câteva scrieri istorice ale lui. / Printre tinerii din Bucovina văd mulţi oameni destoinici şi ambiţioşi, văd şi atâția ambiţioşi fără a fi destoinici, dar între rândurile acelora cari prin situația lor socială nu pot ambiționa prea mult, nu văd cine ar putea lua moştenirea liniştitului lucrător pentru cunoaşterea poporului nostru care a fost părintele Marian.” (22 aprilie 1907) (Marian, 1994) [19].

Etnografia şi etnologia juridică nu sunt în mod evident, particular, delimitate în opera grandioasă a lui Simeon Florea Marian. Abia se constituia ştiinţa generală; nu era timpul pentru dezvoltări particulariste. Foarte târziu, prin altă operă de pionierat, aceea a cărturarului şi antropologului român Romulus Vulcănescu, s-au reflectat şi-n cultura juridică română câteva teme preocupante pentru juriştii noştri, pentru sociologii şi antropologii dreptului. Foarte puține. Şi marele etnolog Petru Ursache a recunoscut că domeniul este deficitar, în chiar impresionanta-i creație de "etnosofie"... (Ursache, 2014a) [20]. Cu toate acestea, încercarea evidentă a etnografului Simeon Florea Marian de evidențiere a propensiunilor populare pentru faptele, conduitele şi judecăţile de valoare fixate pe axa binelui şi de ilustrare a numeroaselor idiosincrazii populare față de atitudinile încolăcite pe axa răului, ca dihotomie kantiană primordială şi ca imemorială moştenire etno-culturală şi religioasă (Marian, 1904), ei bine, toate acestea se pot descoperi oarecum lesnicios de către un "ochi sagace" în această operă "poliedrică" a sa. Apoi, dacă-i recunoaştem valoarea cutumiară, consuetudinară întregii colecții de norme ritualice şi de organizare a vieții ce ne însoțesc, de la naştere, trecând prin căsătorie, şi până la moarte, în timp obişnuit şi în timp de sărbătoare, atunci am putea spune că această delimitare formală nici n-ar mai fi necesară. Ne aflăm pe temelii normative ce sunt comune spiritului juridic şi moral; nu sunt simple moravuri sau 
falkways. Iată, bunăoară, ceva ce pare futil şi neînsemnat, prezența lăutarilor la nuntă, cum, prin interpretare, dobândeşte semnificaţie majoră în comunităţile de români (Marian, 2000) [21]. Genul acesta minor, lăutăresc, a crescut, la rândul lui în rang. La intrarea triumfală a lui Mihai Viteazul în capitala tuturor românilor, Alba Iulia, alături iau fost lăutarii, "opt trâmbiţaşi militari, executând lucrări de paradă, ostăşeşti (Ursache, 2014b) [22]. Dar sunt şi teme grave abordate, precum uzurparea [23], pustiirea [24], piromania [25], tâlhăria şi furtul (mai ales cele ce însoțesc invaziile tătarilor) [26], înşelăciunea [27] şi violenţa, omuciderea [28], cu protagonişti barbari [29], multe dintre ele având drept vectori legendele istorice ale dacilor, ale românilor din toate provinciile româneşti, apărute atât în publicaţii periodice, cât şi în culegeri de-sine-stătătoare (e.g., Legende istorice din Bucovina).

În acest paragraf al lucrării noastre, am putea încadra suma de legende ale păsărilor, legende pe care Simeon Florea Marian le-a adunat în volumele sale sugestive, Ornitologia (Marian, 1883) [30] la români, şi care-au stat la baza inspirației autorilor de mai târziu în ce priveşte extrapolarea fabulisticii narative la un mare bestiar cu valențe simbolice şi cu tâlc juridic şi moral. Şi Ioan Slavici s-a angajat să-i difuzeze, "pentru binele poporului”, lucrarea în Transilvania după ce, mai-nainte, îi ceruse concursul pentru publicarea de articole în primul cotidian al românilor din Transilvania, ziarul Tribuna (Slavici, 1991) [31]. Bunăoară, în ediția Ornitologiei îngriijiă de Ligia Bârgu-Georgeta, întâlnim multe astfel de povestioare, pline de haz, dar, în acelaşi timp, debordând de înţelepciune şi de bune învăţăminte în ceea ce priveşte rostul bun al unor rânduieli ale lumii.

Doar cu titlu de simplu reper cu rol de semnalizare a existenței unor asemenea "fiefuri" de etnografie juridico-morală, completăm studiul nostru exploratoriu cu câteva sugestii. Exempli gratia:

\section{Avatarurile fidelităților, cu virtuţi și vicii}

Povestea adulterului, una aparent facilă, benignă, mereu "fluidă", spumoasă şi perenă şi chiar redundantă în lumea noastră extrem de flexibilă în spațiul moravurilor, dar pe care se pot grefa extrapolări interesante la temele generale ale amoralităţii şi ale volatilității, capriciilor comportamentale din spațiul public (exempli gratia, formarea majorităţilor parlamentare...) şi ale consecințelor lor tardive...

"Legenda cucului: Pasărea, pe care o numim noi astăzi Cucu, cică nu este Cucu cel adevărat, ci soția acestuia, Sava. Cucul cel adevărat, care avea pene de aur nu se află acum pe pământ, ci-n cealaltă lume. Dintru început, cine ştie când a mai fi fost şi aceea, cică trăia Cucu împreună cu soția sa Sava pe pământ, dar fiindcă soția i-a fost necredincioasă, 
Cucu a părăsit-o. Aceasta a fost adică aşa, că Sava s-a iubit cu Privighetoarea. Cucu cică prinzând-o că se iubeşte cu altă pasăre, s-a supărat foarte tare pe dânsa şi-a mustrat-o foarte, zicându-i: "cum de-a putut să se iubească cu Privighetoarea, c-o pasăre aşa de mică şi urâtă, pe când el are pene de aur?’. Apoi, după ce a mustrat-o şi şi-a descărcat tot aleanul inimei sale asupra ei, cică a părăsit pentru totdeauna pământul acesta plin de fărădelege şi răutate (...). Sava, cunoscându-şi greşeala şi voind a se îndrepta, cum a sosit Blagovişteniile (25 martie, Zina cucului sau Buna Vestire, n.m.) a şi început a zbura şi a-1 căuta în toate părțile şi l-a tot căutat până la Sânziene (24 iunie, n.m.), dar nicăieri nu 1-a putut afla.(...)" (Marian, 1987).

2) Corrumpere corrumpo, corrupi, corruptum = a rugini, a descompune, a putrezi, a altera, cu figurativele: a mitui, a seduce, a denatura, a cumpăra conştiințe, a face rău ceea ce era destinat binelui public etc. etc. etc.; într-un cuvânt, rugină morală severă, năruitoare a statelor... (Ocaratoarea mita in istoria romanilor, 2018) [32].

Principiul corupției, însoțit de reflexul natural al răzbunării corupătorului față de cel corupt, cu arme personale care, dacă devin ineficiente, cunosc un adaos filial şi perpetuu, iată o temă perenă. La urma urmei, când îl "cumperi" pe cineva, dobândeşti complexul lui dominus față de servus... şi, în caz de dezamăgitor comportament al servului tău, dai curs unei naturale vendete... Această secvență de psihologie juridică şi morală este cu măestrie reliefată în povestioara "Puii cioarei", culeasă de Simeon Florea Marian în Tomul al II-lea al Ornitologiei poporane române. Iată câteva sugestive excerptae:

"Puii cioarei: A fost odată o cioară, care nu mai avea nicicând parte de puii săi, căci în tot anul venea uliul şi-i mânca. (...) În urma urmelor, după multă frământare şi bătaie de cap, îi plezni prin minte că dacă se va încumetri cu uliul, acesta va avea atâta obraz pe lângă nas şi nu-i va mai mânca puii. (...). (Uliul a acceptat bucuros să se încumetrească şi îi făgădui să nu-i mai mănânce puii, n.m.). (...) Să-mi spui doar cum arată puii tăi, ca să-i pot deosebi de alții. - Puii mei, răspunse cioara cu mândrie, sunt cei mai cilibii şi mai frumoşi dintre puii tuturor paserilor de pe fața pământului. (...) Îmblând uliul, după ce s-a despărţit de cumătra sa, încolo şi încoace şi căutând doară ar putea afla câte una alta de rândul mâncării, nu află decât numai pui de grangură, de cucă, de mierlă şi de alte paseri, adică numai pui frumoşi. Cugetând că sunt puii cumetrei, nu i-a mâncat. (A doua zi, la fel, n.m.). (...) Atreia zi, răzbindu-l foamea (...) dă peste un cuib cu pui de cioară. Şi cum dete cu ochii de dânşii şi-i văzu că sunt atât de urâţi şi de zăbăloşi, nu mai stete mult pe gânduri (...) şi cât ai scăpăra un amnar mi-i puse pre toţi la inimă. (...) - Aşa mi te-ai ținut de cuvânt, cumetre!... Iacă iară mi-ai mâncat puii, mâncate-ar viermii să te 
mănânce!... (...) D-apoi bine, cumătră, dumneata mi-ai fost spus că puii dumitale sunt cei mai frumoşi pui din lume şi nu nişte sluțenii şi uriciuni pre care le-am mâncat eu! Spune-mi, nu-i aşa?... (...) Eu unul mi-am ținut făgăduința, am mâncat ce-a fost mai urât, şi nu ce-a fost mai frumos, după cum mi-ai spus!... (...) Cioara, foc şi pară de mânie, se luă la fugă după dânsul voind să-l prindă şi să-i dea o scărmănătură ca s-o țină minte cât va fi şi a trăi, dacă ar fi avut să mai trăiască. (...) Atâta ştiu, că de atunci şi până în ziua de astăzi, cum văd ciorile pre vreun uliu, totdeauna încep a se fugări după dânsul şi nu se lasă până ce nu-l prind şi-l omoară." (Marian, 1883)

\section{3) Şi-acum, eterna temă a alegerilor...}

Ochiul-boului sau Pănţărușul, singurul din familia Troglodytidae-lor sau, mai bine, impostura, veleitarismul, abuzul, înşelăciunea şi suportul lor peren, viclenia, spiritul furtiv, falsificarea realităţii şi închipuirea, un întreg buchet de "buruieni”" morale şi infracționale se află, toate, concertate într-o sublimă narațiune fabulistică, fixată pe tema alegerilor, şi reprodusă cu măiestrie de către Simeon Florea Marian în al doilea volum al Ornitologiei sale. Aici, vom reproduce doar câteva extrase sugestive:

"Împărățelul: Toate paserile, câte se află în ziua de astăzi pe faţa pământului şi câte se vor mai fi aflat, care astăzi nu mai trăiesc, s-au adunat nu mult după facerea lumii la un loc ca să aleagă pre una dintre dânsele de împărat, carele să aibă apoi a le stăpâni, a le conduce şi a le purta de grijă. Dar, ca şi între oameni, aşa şi între paserile adunate, se iscă dispută şi ceartă mare: cine să fie ales? Care de care se îngâmfă mai tare, care de care se îndesă mai înainte, unele lăudându-şi vița şi sămânța, altele penele, altele îmbletul, altele cântecul şi iar altele zborul, istețimea, priceperea şi îndemânarea. Cu un cuvânt, fiecare se simțea mai presus decât celelalte, fiecare ar fi voit să fie aleasă împărat. (Au convenit să organizeze un concurs de zbor; înălțimea zborului urma să determine învingătorul, n.m.). Vulturul (Marian, 1880) [33] (...), ca unul ce este mai puternic în aripi, ca unul ce-i place a se învârti ore întregi prin înălţimea aerului şi care se poate avânta mai sus decât orişicare pasere, văzând pre celelalte cum cad una după alta amețite, avântându-se cu mândrie deasupra tuturora, socoti în sumeția sa că el va rămânea acuma împărat şi nu altul... Dar iată că (...) Ochiul boului, ascuns fiind de pe pământ sub o aripă a Vulturului, ieşind pe furiş din ascunzişul său, zbură mai sus decât Vulturul. Şi, pe când acuma şi Vulturul, obosit fiind de atâta zbor şi înălţare, se lăsă pe încetul în jos, Ochiulboului începu a ciripi şi a cânta plin de bucurie deasupra lui. Celelalte păsări (...) umplură aerul cu glasuri strigând care mai de care: "Să trăiască Ochiul-boului!... Să trăiască înălţatul nostru împărat!..." (...) Însă, fiindcă multe alte paseri (... aflând despre 
infracțiunile-i de înşelăciune şi fals, de uzurpare nedemnă, n.m.) îi țin până şi-n ziua de astăzi sâmbetele, adică îl pizmuiesc şi numai dacă ar putea l-ar sorbi într-o lingură de apă, de aceea Împăratul paserilor petrece mai mult prin gardurile cele spinoase, prin mărăcini, prin vreascuri, prin tufişe şi pe la rădăcinile copacilor, pentru că numai în aceste locuri are odihnă de dânsele. Când ar petrece prin alte locuri (...), apoi, ce s-ar alege din toată împărăția lui? ... nemică!...” (Marian, 1987) [34].

\section{4) Independenţa judecătorului}

Independența judecătorului este un principiu al dreptului care îşi are explicațiile în nevoia societății de-a determina un centru absolut de echidistanță şi integritate drept garanții ale unui proces echitabil şi ale unei judecâti drepte, juste, dar, pe de altă parte, se explică prin natura sapiențială şi sapientogenă a celui ce ocupă "tronul justiției”, prin calitatea sa esențială, de om liber în spirit, nesupus vreunei ierarhii, slugărnicia şi veninul obedienței servile fiindu-i totalmente improprii. Judecătorul nu "serveşte" pe nimeni", nu este "ministrul" (sclavul public, în sens roman, latin, al termenului) nimănui, el este deasupra tuturor prin forța funcției şi a spiritului său şi, stăpânind toate legile, este hermeneutul lor şi al principiilor interpretative. Deasupra judecătorului sunt doar Dumnezeu şi conştiințta-i curată, nealterată, necoruptă...

Toate aceste calități şi trăsături caracterologice de mai sus, ale celei mai solitare şi sobre funcții publice, aceea de judecător independent şi incoruptibil, precum un "şoim al rândunelelor", transcend planul fabulistic, de vom citi cu atenție basmul "Uliul rândunelelor" inserat în primul volum al Ornitologiei lui Marian. Iată:

"Uliul rândunelelor: După ce şi-au ales paserile "împăratul" şi după ce acuma fiecare şi-a căutat un loc anumit unde să trăiască şi să se hrănească, iată că într-o zi s-au adunat iarăşi la un loc toate acelea, care se țin de sămânţa celor ce mănâncă pre alte paseri şi după ce s-au adunat, ținând sesie întreolaltă, după multă vorbă şi sfat s-au pus pe cale: care preste care să fie mai mare, care sub care să vie şi în ce mod să se arate duşmane oamenilor? Şi aşa, după multă chiteală şi chibzuială, s-au înțeles întru sine, ca Pajura să fie cea mai mare preste toate (...), iară sub Pajură să fie Şoimul, sub Şoim, Hultanul cel negru sau Hultanul de câmp, sub acesta Hultanul alb sau Hultanul de piatră cu grumazul gol, sub acesta (...) Hultanul de piatră cu coada vărgată, sub acesta Cilihoiul (...), sub acesta Caia, sub Caie, Uliul paserilor sau Păsărariul, iară sub acesta şi cel din urmă, Uliul rândunelelor. (...) / Uliul rândunelelor însă, măcar că el dintre toate paserile adunate era cel mai mic şi prin urmare ar fi avut să se supună mai degrabă decât oricare alta, ştiinduse că e mai sprinten şi mai dibaci dintre toate, nu voi nicidecum să se supună hotărârii 
obşteşti, ci zise către celelalte paseri (...): - Da!... cum nu!... mă voi supune şi mă voi teme de voi ca şi când numai voi aţi fi cele mai tari şi mai mari în lume!... Sunt alții de care trebuie să mă tem şi cărora sunt nevoit să mă supun!... De voi nici că-mi pasă!... (...) (nedumerire, n.m.) -Cine!... nici atâta nu ştiți? ... şi totuşi vă dați de cele mai înțelepte şi iscusite vietăți din lume!... Ei bine! Să vă spun eu cel mai mic şi mai neînsemnat dintre voi, pre care 1-aţi pus în fruntea cozii... aceia de care trebuie să mă tem şi cărora nu numai eu, ci şi voi, cu toată isteţimea şi tărimea voastră, trebuie să vă supuneți, sunt puşcaşii! (...) - Dacă n-ați ştiut-o până acum, s-o ştiți de acuma înainte! - Ei! Dacă-i treaba astfel, apoi... ce mai atâta vorbă! Să ne despărțim de laolaltă şi să nu fim mai mult la un loc, căci nici puşcaşilor nu le vom putea aşa de lesne cădea din dămână... (...) Uliul rândunelelor, prin priceperea şi istețimea sa, a ştiut foarte bine cum să se scoată de sub supunerea şi ascultarea care i-au fost menite, fără voia sa, de celelalte paseri din neamul lui." (Marian, 1987) [35].

\section{5) Idiosincraziile perene la spiritul asupritor și tiranic al dictatorilor}

Şi dictatorii au, în simbolistica ornitologică culeasă de etnologul bucovinean Simeon Florea Marian, un exemplar cu care să se "mândrească", unul care, în folclorul nostru național, încarnează răutatea, ticăloşia, abuzul de funcție şi de putere, nedreptatea şi samavolnicia, non-meritul şi scandalul, şi reversul lor, conduita ireverențioasă, abrazivă, vituperantă şi lipsită de respect sau, mai bine, vindicativă şi repulsivă, expresie a nemulțumirii, a urii profunde, a sentimentului de capăt al răbdării, de pahar debordând de venin, sentiment ce încolțeşte, natural, dintotdeauna şi pentru totdeauna în sufletele celor abuzați. Acest simbol este Striga (Tyto alba), din ordinul Strigiformes, ordinul aviar al bufnițelor, de care se tem toți, interpretând funebru şi funest strigătu-i inconfundabil, aducător de nelinişti, de anxietăţi şi panică, precum orice cuvânt al unui veritabil dictator...

"Striga: Zice că Striga dintru început a fost împărăteasă preste toate păsările din lume. Dar fiind foarte rea, mai rea chiar decât o adevărată Strigă sau Strigoaică, asuprind din cale afară pre poporul său şi neîndreptățindu-l cu multe de toate, poporul, nemaiputând răbda, s-a sculat asupra ei şi a voit numaidecât s-o prindă şi s-o omoare. Striga, de frică ca să nu dea cinstea pe ruşine şi să nu i se curme viaţa pentru totdeauna, a spălat putina, ascunzându-se dinaintea poporului său şi de atunci încoace apoi niciodată nu îmblă ziua, ca mai înainte, ci numai noaptea. (...) Şi a avut toată dreptatea să se ascundă, căci până şi astăzi, când văd celelalte paseri pe vreo strigă că zboară ziua, se iau după dânsa şi nu se lasă până ce n-o prinde, iară după ce au prins-o nu se lasă 
nicidecum până ce n-o scarmănă cumsecade. Aceasta e răsplata Strigei, pentru că pe când a fost ea împărăteasă, s-a arătat aşa de crudă şi tirană față cu supuşii ei." (Marian, 1987) [36].

\section{Rolul fabulelor narative de Simeon Florea Marian}

După acest model dezvoltat de Simeon Florea Marian, să observăm, acum, extrapolând la alte animale şi alte simboluri, rolul satiric şi vitriolant al fabulelor narative in raport cu multe tare morale şi, mai ales, cu numeroasele infracțiuni care minează justiția, demnitatea umană, coeziunea şi încrederea unei naţiuni şi fragilizează, dacă nu, aneantizează statul.

\section{1) Impostura funcţiei publice exercitată abuziv, egotic și egofil}

"Lupul pârcălab", din seria basmelor româneşti consacrate imposturii morale a liderilor corupți ce caută în funcția publică pârghia prin care pot propăşi ei şi, eventual, membrii familiilor lor, este o povestire culeasă de la Petre Ispirescu, Poveştile unchiaşului sfătos, p. 287. În colecția lui Ligiei Bârgu-Georgescu (Basme cu animale şi păsări, 1987), o putem încadra în creațiile fabulistice ce sancționează, prin satiră, abuzul în serviciu, delapidarea sau concupiscența, corupția în general.

Asinul, amenințat cu uciderea-i de către lupul flămând, găseşte o strategemă de-a-1 păcăli:

"Poveștile unchiaşului sfătos: - Ascultă. Pârcălabul din satul nostru a murit; toți sătenii ar voi să fie pârcălabi şi din aceasta tot satul este învrăjbit. Mai bucuros ar alege pe un străin, decât pe unul din ei. Şi ca să-şi împlinească dorinţa, mă trimise pe mine să aduc pe oricine voi întâlni. Dumnezeu mi te scoase în cale şi eu te povățuiesc să nu mai întârzii şi să vii cu mine. (...) Pârcălabul, cum se ştie, este capul satului. Oiţele, mieluşeii, găinile, purceii toți sunt sub ascultarea lui. Pe fiecare zi vei putea alege câte una pentru prânzul dumitale, fiindcă pârcălabul nu este aşa degeaba pârcălab. - Dacă este aşa, te ascult, haide să mergem. (...) Abia ajunseră la marginea satului şi asinul o rupse de fugă; lupul, după el. Țăranii, văzând că intră lupul în sat, săriră cu mic cu mare, cu ciomege, cu topoare, cu bulgări, dădură chiote, îl loviră şi luară pe lup cu câinii. Cât p-aci să-i rămână pielea pe-acolo. (...) În pădure, pe jumătate mort, lupul medită: "- Moşii mei pârcălabi n-au fost, tatăl meu, asemenea, n-a fost pârcălab, cine mă puse pe mine a crede că eu aş fi bun de o asemenea slujbă? Rămăsei şi nemâncat. Crăp de foame şi de osteneală. N-are cine mă lua de coadă şi să mă învârtească, până mi-o rupe coada, încai să mă aleg cu atât." (Un călugăr pripăşit prin preajmă, n.m.) n-aşteptă să mai zică încă o dată lupul 
ceea ce credea el că-şi spune numai lui însuşi şi făcu tocmai precum se temea lupul, că nu o să se găsească nimeni să-i facă şi ăst neajuns."

2. Satira necen₹urată, libelul defäimător şi rolul lor tămăduitor pentru indreptarea moravurilor societătilor "bolnave"

"Tăunele socratic" sau forța ridiculizantă a satirei, a libelurilor defăimătoare dintotdeauna faţă de slăbiciunile omeneşti, de spiritul filo-infracțional şi imoral. Tradiția fabulelor lui Esop şi a satirelor dintr-un imaginar Satyricon perpetuu al lui Petronius [37], tradiția lui La Fontaine şi a lui Dimitrie Cantemir (Istoria ieroglifică şi fabula satirică necruţătoare privind lupta pentru putere între Inorog şi Corb, alias Cantemir şi Brâncoveanu) s-au văzut continuate la noi în întregul secol XIX, ba chiar şi în secolul XX, dac-ar fi să ne gândim la Motanul Arpagic al Anei Blandiana. Într-o lucrare recent susţinută la o conferință la Universitatea de Stat din Chişinău, exprimam următoarele:

"Secolul al XIX-lea românesc a înregistrat apogeul fabulisticii în toate provinciile istorice, de la Nistru până la Tisa. După satirele lui Antioh Cantemir [38], ctitorul Academiei Domneşti din Iaşi (1707) şi consolidarea trendului ascendent al criticii sociale moral-juridice prin moldoveanul Gheorghe Asachi (Asachi, 1844), munteanul din Târgoviştea voievodală a Basarabilor, Grigore Alexandrescu (Alexandrescu, 1863) şi bănățeanul Dimitrie Țichindeal (Țichindeal, 1975), tustrei fiind şi veritabili pilaştri de bază ai templului conştiinței naționale, după aceste remarcabile fenomene, scena este ocupată de basarabeanul orheean Alecu Donici, care se desăvârşeşte profesional, prin calitatea de preşedinte al Judecătoriei Neamţ, la Piatra Neamț, iar literar, prin publicațiile şi funcțiunile culturale de la Iaşi. Aprecierile ce ne vin de la Mihai Eminescu faţă de această generație de aur a fabulisticii româneşti, în cunoscuta-i poezie Epigonï, lasă loc de puţine comentarii. Iată câteva excerptae:

Văd poeţi ce-au scris o limbă, ca un fagure de miere / Cichindeal gură de aur, Mumulean glas cu durere, / Prale firea cea intoarsă, Danïl cel trist şi mic, / Văcărescu cântând dulce a iubirii primăvară, / Cantemir croind la planuri din cuțite si pahară, / Beldiman vestind în stiburipe răz̧boiul inimic. / Liră de argint, Sibleanu - Donici cuib de-nțelepciune, Care, cum rar se intampla, ca să mediteze pune / Urechile ce-s prea lunge ori coarnele de la cerb; / Unde-i boul lui cuminte, unde-i vulpea diplomată? / S-au dus toți, s-au dus cu toate pe o cale nenturnată. / S-au dus Pann, fiul Pepelei, cel isteț ca un proverb.

Ca-n orice dezvoltare naturală, organică, acestei epoci avea să-i fie contrapusă o alta, a jurnalismului pasionant, aducând cu sine, în avanscena criticii de moravuri şi de atitudini infracționale, a criticii sociale şi juridice în general, caricatura, benzile desenate, 
până la această contemporană epocă ce limitează forța de cândva a jurnalismului prin forța directă a telematicii, a instantaneităţii comunicaţionale şi prin virulenţa în progresie geometrică a rețelelor de socializare, prin sloganurile extrem de sugestive, de percutante, precum acelea din cadrul manifestațiilor gigantice de stradă ale mişcării \#Rez̧ist din România anilor 2017-2018. / Cu toate acestea, viața juridică şi morală a cetății nu poate aneantiza amintirea prețioasă pentru asanarea moravurilor şi îngrădirea infracțiunilor a alegoriei fabulistice şi a libelurilor defăimătoare de cândva. Acestea au cunoscut mulți detractori (din partea celor vizați sau a acelor care "s-au simțit cu musca pe căciulă", pentru a vorbi româneşte...)." (Ciucă, 2018).

Povestioara "Musca şi puricele", pe care autoarea a inserat-o în colecția sa, fiind culeasă din revista Ion Creangă, transcrie, pe filiera primului nostru etnograf veritabil, cu adaptările revuistice şi folcloristice această revistă populară, transcrie în termeni românești tocmai ideea necesarei satire, critici, libelului defăimător, jucând rolul "tăunelui socratic", ce-l mişcă din loc pe nepăsătorul animal de tracțiune. Iată:

"Musca şi puricele: (...) - Da de ce eşti ghebos, măi frate purice?

- Da cum cioarele n-oi fi ghebos, dacă toată noaptea ridic ca robul la butuci şi la bolovani şi-i duc peste oameni ca să le fac drum mare pe spinare... Şi tu, muscă, ce eşti aşa cu ochii umflați?

- Apoi cum boala nu mi s-or umfla ochii, dacă râd cât îi ziua de mare? De multe ori mă țin cu mâinile amândouă de pântece şi gândesc că dau din mine pe ochi de atâta râs.

- SSi de ce râzi tu aşa, muscă hăi?

- Ia, mâ pun pe ochi, pe frunte, pe nas, unde se gâdilă omul mai al naibii şi când bietul om să mă pleznească, eu fug. Şi aşa, pălindu-se singur, omului îi iesă ochii de durere şi de ciudă, iar mie îmi iesă ochii de râs şi de bucurie.” (Revista Ion Creangă, anul V, nr. 7, 1912) (Basme cu animale şi păsări, 1987).

3. Justiţia sau echitatea (aequitas)

Justiţie în mod egal îndreptată împotriva ignoranței, stupidităţii, neglijenței, indolenței, incompetenței, mal praxis-ului, cum se spune acum, cât şi împotriva vicleniei, înşelăciunii, simulării şi disimulării, spiritului falacios profund imoral şi ilegal, profund infracțional, delictual, denaturând morala publică sănătoasă. Povestirea "Doi şoareci" este, în acest sens, edificatoare pentru propensiunea populară românească, dar şi pentru aceea a culegătorului de folclor, față de buna morală publică. Iată: 
"Doi şoareci: Odată, aproape de iarnă, s-a întâlnit un şoarece de câmp cu unul de casă. Şoarecele de câmp zise celui de casă:

- Ce-ai strâns tu pentru iarnă, că eu am făcut nouă mişini pe câmp?

- Hai de mi le arată, apoi îți voi arăta şi eu pe ale mele, zise cel de casă.

Se duseră şi văzură cele nouă mişini, veniră în sat, intrară într-o casă spre a vedea agoniseala celui de casă. Umblând ei fără frică prin lăzi, prin sacul cu făină, prin cel cu păpuşoi, cutreierară toată casa şi când era aproape să-l fericească cel de câmp pe cel de casă, văzură într-un colț al casei, stând şi pripindu-se la foc, o pisică; atunci, cel de câmp îl întrebă pe cel de casă:

- Dar aia din vatră ce este?

- $\quad$ Este naşul nostru, zise cel de casă; când vei trece pe lângă el, să-i săruți mâna.

Când voiră să treacă şi ei prin vatră, pisica (D.N.A. românească, în variantă update, n.m....) îi primi bucuroasă cu amândouă mâinile şi-i pupă frumuşel, aşa că amândoi sărutară mâna naşului, şi prostul şi vicleanul.” (Revista Şezătoarea, anul X, vol. VII, 1903) (Basme cu animale şi păsări, 1987).

4. 'Unde-s multi, puterea cresste"...

Forța societăţii civile, diversificate, "poliedrice", reactive, vii, sensibile şi concentrate, unită prin ideal moral, precum, mutatis mutandis, \#Rezist, faţă de dictatură şi de puterea politică sau politicianistă pură, cristalizată pe o obsesie sau pe un fetiş, pe hoție, vicleşug şi nemerit, unilaterală şi neimaginativă, previzibilă şi ignobilă, închistată şi neadaptabilă, ei bine, toate aceste virtuţi şi vicii fixate pe entităţi diferite, dar definind aceeaşi societate şi acelaşi stat, pot fi descoperite, într-o manieră concentrată şi fabulistică descrise, în basmul putnean "Baba şi uncheşul" şi-ntr-o serie de alte basme, precum "Câinele salvat de pisică", Ariciul şi vulpea", "Cu oul", dar, mai ales, în excepționalul basm ilustrativ al acestei teme, "Animalele solidare", identificat, ca atare, mai târziu, şi-n Albeştii Argeşului. Iată-l prezentat în forma-i narativă:

"Animalele solidare: A fost odată un măgar şi măgaru-ăsta s-a plictisit stând la stăpânu-su. Ce s-a gândit el, zice:

- Mă, o să plec în lumea asta, nu mai vreau să mai stau la stăpân!

A plecat el, a mers ce-a mers, se-ntâlneşte c-un câine:

- Ce faci, mă, aici?

- Ce:

- -Uite, ce să fac, zice, m-a cam bătut stăpânu, zice, şi ce să fac? Să fug. 
- Ce:

- Hai cu mine, zice, să mergem amândoi mai departe.

- SSi-uite-aşa, pe drum, s-au mai întovărăşit cu un cocoş, cu un ou, un rac, o albină.

Au ajuns în pădure, pe înserat şi s-au adăpostit într-o casă părăsită. Peste noapte, au fost călcați de hoți. Când intră acolo, măgaru-ncepe să zbiere. Câinele începe să latre. Un hoț, de-nvălmăşeala aia n-a ştiut ce să mai facă. S-a dus să facă focul, să se-ncălzească. Ce să vezi? Când suflă-n foc, oul a pocnit. I-a scos ochii cu cenuşă. El nu mai vedea; să duce la căldare, când ia apă să se spele, racu-l apucă de degete şi i le tăie. Când a văzut iel aşa, s-a dus să ia prosopul să se şteargă pe ochi, acolo albina 1-a-nţepat. Acum, când să iasă afară, cocoşul din pod: - Cotcodac, cotcodac! El a crezut că strigă: - T,âneți-l să-1 prinz eu!

Şi să te păzeşti, hoții au fugit, acuma ei au rămas stăpâni în casa aia. Şi cred că şiacuma-s, dacă nu i-o mai fi necăjit cineva. Şi atât a fost povestea." (mg. 1241 c. Albeşti Argeş, 1957) (Basme cu animale şi păsări, 1987).

\section{Radix, radici...rădăcină, rădăcinï...}

Spiritul stenic, "rădăcinos", aşezat, al celor care nu disperă, ci rezistă şi încearcă, chiar fără imediat folos sau şanse de succes, să transforme mediul lor inacceptabil sub aspect moral, într-unul bun prin prisma mai multor criterii existențiale; cu alte cuvinte, "Fie pâinea cât de rea, tot mai bine-n țara ta..."; este o arhicunoscută maximă populară ilustrată în povestirea "Purcelul în oi":

"Purcelul în oi: Un purcel odată era alb ca ghiocul. Ce s-a gândit?

- Părul meu e tot ca lâna oilor de frumos şi de alb. Cât o să stau între nespălații ăştia?

Hai mai bine să fug dintre ai mei şi să mă duc la oi.

S-a dus. Oile s-arătau vesele nevoie mare şi-1 arătau la toată lumea. Şi a stat cât a stat. Dar, prietenul la nevoie se cunoaşte. Uite că-ntr-o zi vine lupul în oi şi se repede mai întâi la purcel, că l-a văzut mai mic. El însă s-a ținut bine; dar oile, în loc să-l apere, au fugit care încotro au văzut cu ochii. Purcelul s-a luptat ce s-a luptat cu gadina; iar pe urmă, dacă s-a văzut părăsit, s-a gândit: - I... ai mei nu m-ar fi lăsat singur! Şi s-a repezit iar în turma de porci, de unde n-a mai plecat." (Rădulescu-Codin, 1930; Basme cu animale şi păsări, 1987).

\section{Concluzii}

Literatura sapiențială şi consuetudinară, populară, folclorică, orală, pe care acest venerabil polihistor al culturii româneşti a cristalizat-o pentru totdeauna în forme 
scriptice şi hermeneutice marcate de precizie ştiințifică, reprezintă un teren fertil şi demn de-a fi exploatat noetic şi pentru tinerii jurişti de astăzi, mai dedicaţi jusnaturalismului, valorilor juridice perene, principiilor şi moralităţii, decât generaţia pozitiviştilor ultraformalişti, legalişti, mărginiți de expresiile inconfortabile ale normelor dotate doar cu text, nu şi cu sens, în cel mai rigid şi kelsenian mod cu putință. Tot pentru întărirea spiritului junimii române i s-a cerut ajutorul intelectual lui Simeon Florea Marian, "amfitrionul" nostru magnanim de astăzi, de către un alt tânăr în momentul de referință, poetul Octavian Goga... (Goga, 1903) [39]. Fără a fi o demonstrație exhaustivă, ci doar o invitație, printre altele, la descoperirea valorii sapiențial-juridice şi a celei jusnaturalistmoralizatoare, spirituale, a creațiilor populare românești, în concertul mai larg, european, acela al lucrărilor cu "îndiguiri" apoftegmatice, sapientogene, prezenta lucrare ar putea juca doar rolul de paladium, de catalizator pentru eventuale combustii intelectuale pe teren juridic.

\section{Surse de informații:}

Alba, I. (2018). Arcul şi săgeata" într-o "iconografie" socio-juridică centenară" Centenarul Uniria romanilor si Europa de azi. Religie si geopolitica. II, volum colectiv. Universitas Napocensis. Presa Universitara \& Ed. Reintregirea.

Alexandrescu, G.M. (1863). Meditații, elegii, epistole, satire și fabule. București.

Asachi, G. (1844). Fabule versuite. Mădular Academiei de Roma şi al mai multor societăţi învăţate. Ediţia a treia, adăogită. Iaşii: Institutul Albinei Româneşti.

Basme cu animale şi păsări (1987). Ediţie îngrijită şi prefaţă de Ligia Bârgu-Georgescu. Bucureşti: Minerva.

Brădățan, A.D. (2007). Complexul Muzeal Bucovina Suceava. Casa Memorială Simion Florea Marian. Suceava: Lidana.

Brădățan, A.D. (2017). Omagiu academicianului Simion Florea Marian. La 170 de ani de la naştere. Anuarul Muz̧eului Bucovinei, XLIV ,326. Suceava: Universitatea "Ştefan cel Mare".

Bumbac, V. (1906). Societatea Clubul Român din Suceava. În Românii din Bucovina.

Ciucă, V.M. (2017, martie 17-18). Virtuți şi vicii intr-un libellus diffamatorius. Evoluții juridice în serviciul onoarei. Excerptae. Țn cadrul Conferinței Naționale „The Influence of Personal Data Protection within the Business Environment; New 
Challenges of the General Data Protection Regulation". Târgu Mureş: Universitatea "Petru Maior".

Ciucă, V.M. (2018, martie 22-23). Judecătorul şi fabulistul orheean Alecu Donici, precursor al etnologiei juridice românești. Conferința Ştiințtifică Internațională, consacrată Centenarului Marii Uniri cu genericul "Revenirea Basarabiei în spativil juridic românesc”. Chişinău: Universitatea de Stat Chişinău.

Cojocaru, N. (2001). O nouă contribuție cu privire la etimologia refrenului "Ler Doamne" în colindele româneşti. Anuarul Mužeului Etnografic al Bucovinei, Făt Frumos, III, 3. Suceava: Publismeditor.

Cosma, V.S. (Ed.) (2013). Preotul "folclorist": de la combaterea "superstiţiilor" la culegerea folclorului. Studiu de caz: Simion Florea Marian. Conferinţela de vară de la Telciu, I, Telciu, 20-21 iulie 2012, Incluşi şi excluşi. Problema identitară în epocile modernă şi contemporană. Cluj-Napoca: Editura EIKON.

Goga, O. (1903, dec. 3). Scrisoare către Simeon Florea Marian. În Simion Florea Marian şi corespondenții săi.

Haşdeu, B.P. (1882, martie 12). Discurs de răspuns la cel de recepție al lui Simeon Florea Marian cu ocažia primirii acestuia din urmă în Academia Română. Apud Aura Brădățan, op.cit. (Complexul...).

Hăulică, I. şi Cotea, V.D. (Eds.) (1998). Marţian Cotrău aşa cum a fost. Iaşi: Apollonia.

Jucan, G. (1999). Mihai Eminescu despre Suceava, împrejurimile ei şi câteva aspecte de etnografie. Anuarul Muzeului Etnografic al Bucovinei. Făt Frumos, I, 1/1999. Suceava: "Suceava".

Loghin, C. (1996). Istoria literaturii române din Bucovina, 1775-1918. Cernăuți: Alexandru cel Bun.

Marian, S.F. (1904) Legendele Maicii Domnului. Studiu folcloristic. Ediţiunea Academiei Române. Bucureşti: Institutul de arte grafice Carol Göbl.

Marian, S.F. (1995). Naşterea la români. Nunta la români. Inmormântarea la români. Studiu etnografic. Vol. I-III. Ediție critică de Teofil Teaha, Ioan Şerb, Ioan Ilişiu, Text stabilit de Teofil Teaha, Editura Grai şi Suflet. Bucureşti: Cultura Naţională (in integrum).

Marian, S.F. (2000). Naşterea la români. Nunta la români. Inmormântarea la români. Ediție îngrijită de Iordan Datcu. Bucureşti: Editura Saeculum I.O.

Marian, S.F. (1994). Oameni cari au fost. Vol. I. Studiu introductiv de Valeriu Râpeanu. Ediție critică, note şi comentarii de Valeriu Râpeanu şi Sanda Râpeanu, Galați: PortoFranco. 
Marian, S.F. (1987). Ornitologia. Vol. I. Apud Basme cu animale şi păsări, Ediție îngrijită şi prefaţă de Ligia-Bârgu-Georgescu, Ed. Bucureşti: Minerva.

Marian, S.F. (1883). Ornitologia poporană română. Vol I. Cernăuți: Tipografia lui R. Eckhart. Marian, S.F. (1880). Pajura. O eroină a poveştilor noastre. Albina Carpaților, IV, 22-24.

Marian, S.F. (2015). Sărbătorile la români (Cârnilegile, Păresimile, Cincizecimea). Vol. I-III. Colecţia Mythos (in integrum). Ediție îngrijită şi introducere de Iordan Datcu. Bucureşti: Editura Saeculum I.O.

Nestor, O. (2000). Colegiul Naţional "Ştefan cel Mare" la 140 de ani de la înființtare". Anuarul Muzeului Etnografic al Bucovinei Suceava "Făt-Frumos", II, 2/2000, 354-355. Suceava: Suceava.

Ocaratoarea mita in istoria romanilor (2018, November 11). Retrieved January 17, 2020 , from https://www.historia.ro/sectiune/general/articol/ocaratoarea-mita-inistoria-romanilor

Olteanu, A. (2000) Cuvânt înainte. În: Marian S.F. Mitologie românească. Ediţie îngrijită, cuvânt înainte şi note de Antoaneta Olteanu. Bucureşti: Paideia.

Paul Leu. Introducere. Marian F.S. Legende istorice din Bucovina. Ediţie îngrijită cu note şi studiu introductiv de Paul Leu. Iaşi: Junimea.

Rădulescu-Codin, C. (1930). Îngerul Românului. Povești şi legende din popor. Bucureşti.

Regele ca sinecdocă a Justiției (2017) Capitol în Al. Muraru \& Daniel Şandru (coordonatori), Reîntoarcerea. După 20 de ani. Două decenii de la revenirea în țară a Familiei Regale a României, Ed. Corint.

Slavici, I. (1991). Scrisoare către Simeon Florea Marian. în Simion Florea Marian şi corespondenții săi. Ediție îngrijită de Eugen Dimitriu şi Petru Froicu. Cuvânt înainte de Iordan Datcu. Seria "Documente literare". Bucureşti: Minerva.

Suport scriptic al comunicării pregătite pentru Conferinţa ştiinţifică internațională, consacrată Centenarului Marii Uniri cu genericul "Revenirea Basarabiei în spațiul juridic românesc" (2018, martie 22-23). Academia de Ştiințe a Moldovei. Chişinău: Universitatea de Stat Chişinău.

Tacitus (2017). Annales, 3, 6, 789. Theofil Simenschy, Dicționarul înțelepciunii. Cugetări antice şi moderne. Ediția a doua, augmentată şi corijată. Ediţie îngrijită după manuscris şi prefaţă de I. Oprişan. Bucureşti: Saeculum Visual.

Țichindeal, D. (1975). Fabule şi moralnice invăţături. București: Facla. 
Tradiţii normative şi judiciare romanesti. Reevaluări după o sută de ani de unitate naţionala. Conferinţă „România. Cultură şi civilizație”, 19.VII.2018. În cadrul Cursurilor de vară, pentru studenții străini. Iaşi: Univ. „Al.I. Cuza”.

Ursache, P. (2014.a). Antropologia, o știință neocolonială. Ediţie revăzută de autor. ClujNapoca: EIKON.

Ursache, P. (2014.b). Etnoestetica sau mic tratat de estetică a artelor oralității. Ediție revăzută şi augmentată de autor. Cluj-Napoca: EIKON.

Virtuți şi vicii într-un libellus diffamatorius (2017). Evoluții juridice în serviciul onoarei. Excerptae. Volum colectiv Protecția datelor cu caracter personal, coordonatori: Irina Alexe, Dragoş-Nicolae Ploesteanu, Daniel-Mihail Şandru. Bucureşti: Editura Universitaria.

Vrabie, G. (1968). Folcloristica română: Evoluţie, curente, metode. Bucureşti: Editura pentru Literatură.

\section{Note}

[0] Tacitus. Annales, 3, 6: "Domnitorii sunt muritori, pe când țara e eternă", apud Theofil Simenschy, Dicționarul înțelepciunii. Cugetări antice şi moderne.

[1] Key speaker: "Chipul Cuvântului şi chipul judecătorului în sentenții româneşti. "Arcul şi săgeata" într-o "iconografie" socio-juridică centenară", Conferința Internaţională dedicată Centenarului unităţii româneşti, Universitatea "1 Decembrie", Alba Iulia, 15 mai 2018. Vezi şi "Chipul Cuvântului şi chipul judecătorului în sentenții româneşti. "Arcul şi săgeata" într-o "iconografie" sociojuridică centenară", in Centenarul Unirii romanilor si Europa de azi. Religie si geopolitica, Vol. II, volum colectiv, Universitas Napocensis. Presa Universitara \& Ed. Reintregirea, Alba Iulia, 2018.

[2] Suport scriptic al comunicării pregătite pentru Conferința ştiințifică internațională, consacrată Centenarului Marii Uniri cu genericul "Revenirea Basarabiei în spațiul juridic românesc", Academia de Ştiințe a Moldovei, Universitatea de Stat Chişinău, în perioada 22-23 martie 2018, Judecătorul şi fabulistul orheean Alecu Donici, precursor al etnologiei juridice româneşti. Contribuții la redactarea Rezoluției Conferintei transformate in Congres ad hoc pentru unificarea ştiinţelor juridice româno-basarabene. 
[3] Aequitas şi officium pietatis, valori juridice romane asociate unionismului românesc, decantate în "retortele" paşoptiste europene, Conferință, în cadrul Colocviului Internaţional "România şi Italia. Cultura comună a memoriei ultimilor 100 de ani. Memorie şi identitate în dialogul româno-italian: spații simbolice, aspecte juridice, istorice şi filosofice", organizat de Centrul de Studii Internaționale şi Drepturile Omului din cadrul Institutului Transfrontalier de Studii Internaționale şi Justiţie Penală al Universităţii «Dunărea de Jos» din Galați, cu colaborarea Facultăţii de Istorie, Filosofie şi Teologie a aceleiaşi instituții de învăţământ superior, a Institutului de Cercetări Juridice «Acad. Andrei Rădulescu» din Bucureşti al Academiei Române, Associazione degli Studiosi di Diritto Internazionale ed Europeo din Roma, Institutului Român de Cultură şi Cercetare Umanistică de la Veneția, Accademiei di Romania din Roma, Institutului «Eudoxiu Hurmuzachi» pentru românii de pretutindeni, Centrului de Documentare Europeană de la Universitatea «Dunărea de Jos», împreună cu Fondazione Ugo Spirito e Renzo De Felice di Roma, Galați, 23-24 nov. 2018. Vezi şi volumul colectiv aferent Colocviului, publicat de Editura Aracnee, Roma, 2018

[4] Exempli gratia:

"Calea neprihăniților” sau calea judecății celor virtuoşi (justorum). Despre (ne)studiul deontologiei judiciare. Prosopopeea romanistă, canonică şi cutumiară a Codului civil napoleonian. Dedicație carbonnieristă pentru revista Timpul, la Bicentenarul acestei opere”, secțiune în cadrul cărții intitulate „Despre jurişti”, Ed. Universul Juridic, Bucureşti, 2017, pp. 119130, sub editarea doamnelor Raluca Bercea şi Alexandra Mercescu;

"Statul de drept şi legile Justiţiei. Elogiu raţiunii judecătorului independent. Habermas sau Pescatore ?" Interviu realizat de doamna Ioana Ene Dogioiu, Senior editor la publicaţia electronică Ziare.com, cu Valerius M. Ciucă 01.XI.2017 ;

„Despre dubla misiune, de profesor si de judecator”, in Vasile Lucian Arhire, Ghici cine vine la cină, Ed. Iasi, interviu cu Valerius M. Ciucă, transcris într-un capitol al cărții, în Vasile Arhire, Ghici cine (re)vine la cină, Vol. I, Ed. Junimea, Iaşi, 2017, pp. 219 et sq.;

Despre justitie si judecători. Interviuri, Ed. Universitară, Bucureşti, 2010, 270 pag., coautor;

Deontologie judiciară. Syllabus, Ed. Sedcom Libris, Iasi, 2009, 300 pag., coautor; 
La justice française de la justice statistique à la négation de la justice (coautori Marc Richevaux, Brice Mankou), ISAM, Caietul stiintific 6, Chisinau, 2014;

L'idée européenne d'indépendence du juge et son impact dans les démocraties émergentes, coautor, ISAM,Caietele Institutului de Studii Administrative, nr. 4, Chisinau, 2011;

"Juriştii sunt titularii Infernului. Trăiesc în infernul relaţiilor umane", interviu, Revista electronică Cuzanet, 02.II.2017;

De nouveau, sur la „laisse d'un chien de garde”. Sur l'équité du juge ou la „transgression” méthodique et légitime, Paris, pentru Buletinul colectiv al Bicentenarului Baroului, 2010 si pentru Le cahiers de l'ULCO, Saint Omer, decembre, 2013;

„Despre transgresivitatea judecatorilor”. Interviu, Juridice. Ro, in dialog cu Dan Stoica, 2010;

„Judecătorii. Interviu”, în revista „Forumul judecătorilor”, nr. 1/2010, București;

Valerius M. Ciucă in dialog cu Andrei Savescu. Despre judecători, învațământul juridic şi justiție, 1 iulie 2011, Juridice.ro;

Despre creativitatea judecatorului si rolul lui in constructia unei noi culturi juridice europene, „Curierul judiciar” nr. 7/2010, pp. 367 sq.;

Valerius M. Ciucă în dialog cu Dan Stoica despre drept, judecători şi elegantia juris, 16.11.2008 | JURIDICE.ro

[5] "Începându-şi ucenicia sub influența şcolii romantice creată de Vasile Alecsandri, reorientându-se şi perfecţionându-se la cea ştiinţifică a lui B.P. Haşdeu, S. Fl. Marian marchează un nou moment în dezvoltarea folcloristicii şi, mai ales, în crearea etnografiei româneşti. Dacă Alecsandri, Haşdeu. G. Dem. Teodorescu, Mozes Gaster ş.a. purced de la teoretizarea ştiinţei folclorice la cunoaşterea propriu-zisă a folclorului, Marian a făcut calea inversă. El a plecat de la investigarea concretă, nemijlocită, multilaterală a creației literare orale spre interpretarea ştiințifică a acesteia, deschizând astfel calea unor cercetători ca Tudor Pamfile, Artur Gorovei ş.a." (Paul Leu)

[6] "Pe de altă parte, din postura de "intelectual", de om învăţat a cărui muncă avea şi pronunţate conotaţii patriotice (în sensul că preotul trebuia să lucreze pentru rădicarea şi luminarea poporului şi pentru propăşirea culturii naţionale), preotul apare în postura de persoană care are acces la zestrea culturală şi spirituală a naţiunii. În efervescența Romantismului şi în prelungirea tezelor herderiene şi ale 
exemplelor date de frații Grimm şi alții ca ei, preotul avea datoria patriotică, pe de o parte, şi responsabilitatea ştiințifică, pe de altă parte, de a nu lăsa astfel de "comori”" să piară." (Cosma, 2013, p. 66)

[7] Pentru o tratare detaliată şi nu rareori în termeni poetici (e.g., "Un pui de bucovinean în şcoala germană"; "Prigonit în propria țară, pribeag prin Transilvania"; "Autorul cărții de aur a țăranului român, în cultura lumii" etc.), a se vedea Cap. I, "Simion Florea Marian, o viaţă în slujba culturii neamului românesc", în Aura Doina Brădățan, Fondul memorial-documentar Simion Florea Marian din Suceava. Istoric. Contribuția la cultura română (Teză), Muzeul Bucovinei, Ed. Karl A. Romstorfer, Suceava, 2013, pp. 21-53. Este o lucrare recenzată de Prof. Dr. Mihai Iacobescu, sub titlul sugestiv pentru valoarea ei, şi cu referire la autoare, doamna Aura Doina Brădățan, ca la o "vestală slujind într-un templu". A se vedea, în acest sens, titlul eponim în Suceava. Anuarul Muzeului Bucovinei, XLI, Editura Universității "Ştefan cel Mare" din Suceava, 2014, pp. 365-368.

[8] Tehnoredactare Iuliana Roşca: "Simion Florea Marian învață să scrie şi să citească de-abia la 12 ani (...) într-o căsuță micuță căreia i s-ar şedea orice să fie numai şcoală nu... Şcoala e numai o clasă. Odaia şcolii e atât de mică, încât punându-se copiii ca scrumbiile în poloboace, totuşi n-ar încăpea mai mult de şaizeci... Într-o asemenea odăiță e vai şi amar de copiii românilor, scria Marian, după două decenii de la absolvire." (Brădățan, 2007, 6).

[9] Aura Brădăţan, op. cit. (Complexul...), p. 7.

[10] Prof. Univ. dr. Ion Popescu-Sireteanu, "Studiu introductiv. Simion Florea Marian în amintirile contemporanilor", în Muzeul Etnografic al Bucovinei, Suceava, Simion Florea Marian în amintiri, mărturii, evocări..., Antologie, text stabilit, note, tabel cronologic şi bio-bibliografic de Petru Froicu şi Eugen Dumitru, Postfaţă de prof. Drd. Nicolae Cârlan, Editura "Suceava", 1997, p. 8.

[11] I. Popescu-Sireteanu, loc. cit., p. 8: "(...) elevilor români le era foarte sever oprit de a vorbi întreolaltă româneşte. Şi dacă totuşi se întâmpla ca oarecare elev român să vorbească în limba sa, atunci i se anina de cât un chip de măgar tăiat din hârtie ori zugrăvit pe pe o tablă de lemn, de care era legată o ață. Şi măgarul acesta trebuia să-l poarte elevul român în cursul întregii săptămâni până sâmbătă. Sâmbătă elevii din toate clasele erau chemați la un loc şi toți aveau dreptul de a scuipa asupra păcătoşilor români, care aveau chipurile de măgari la gât. Va să zică, pentru vorba românească, îi ruşinau şi-i scuipau pe copiii români (Loghin, 1996, 33) 
[12] Valerius M. Ciucă, "În memoria unui bihorean de seamă, fiu adoptiv al Iaşului, prof. dr. doc. Marțian Cotrău", in http://juridice.ro/essentials/480/in-memoria-unuibihorean-de-seama-fiu-adoptiv-al-iasului-prof-dr-doc-martian-cotrau, reproducere a articolului din Rev. Epifania, nr. 30/2014

[13] "După terminarea şcolii primare, "Doamna" le-a spus părinţilor mei că "băiatul e bun la carte" şi "să-l dea mai departe". / Aşa am ajuns la Liceul "Samuil Vulcan" din Beiuş, unde, datorită unor profesori de excepție, mi s-au deschis porțile culturii. Pe lângă instrucția liceală, am beneficiat şi de contribuția educativă şi culturală a călugărilor asumpționişti de la Internatul Paulian. Figura de prim plan în acest internat era Père Merloz, personalitate de o vastă cultură, dublată de o mare capacitate charismatică. Pe de altă parte, de la Père Nicolas, am deprins, toți interniştii, gustul pentru drumeție. În acest mediu francofon, pe lângă completarea cunoştinţelor de limba şi literatura franceză, am găsit şi motivaţiile de-a respinge ideologiile extremiste care circulau atunci, mai ales printre tineri." (Hăulică \& Cotea, 1998, p. 12)

[14] "Înfiinţarea Gimnaziului Ortodox-Oriental din Suceava este un proces firesc al trezirii conştiinţei de sine a românilor din Suceava şi împrejurimi. Această şcoală este văzută, cu luciditate, nu ca un dar venit din partea ocupanților, ci ca o izbândă a obştii româneşti din Suceava. Că românii din Bucovina (ca, de altfel, şi cei din Transilvania, şi din Basarabia, n.m.) au fost nevoiți sî înfrunte planurile inginereşti de deznaționalizare ale ocupanților prin îndepărtarea de propria credință şi de propria limbă nu este de mult o noutate. Şi totuşi, nu poţi să nu te înfiori citind o ordonanță a autorităților din Viena din 1816: "Nici un naţional român nu se va primi în învăţământ, dacă nu va jura înainte că se leapădă de credinţa ortodoxă.”... (Nestor, 2000, pp. 354-355)

[15] "Unul din cei mai buni pedagogi, blândul nostru catehet", cum avea să-1 caracterizeze un absolvent al Liceului Greco-Oriental, azi Colegiul Naţional "Ştefan cel Mare" din Suceava (Marian, 1995, p. 159).

[16] I. Popescu-Sireteanu, loc. cit., p. 10: 'Este interesant să aflăm că în casa socrilor săi din Siret a fost şi Eminescu (cum crede Lucian Costin). Unul din marii oaspeți ai familiei Marian la Suceava ar fi fost Mihai Eminescu, în timpul când acesta o vizita pe sora sa Aglaia sau când îşi vizita prietenii: Vasile Bumbac şi Ştefan Dracinschi. Când a dat mâna cu el, mama a rămas fără glas: ochii lui erau adânci, privirea 
pierdută parcă, iar mâna rece ca a unui mort (Maria Cărăuşu) Eugen Dimitriu crede că Eminescu ar fi fost oaspete al familiei Marian în 1885."

[17] Suceava e pentru el Vatra aşezării Moldovei, stupul de unde au pornit roiurile care au împoporat T, Tara de Jos, mormintele domnilor, vechea sa capitală, Mitropolia sa veche (...) - Căci acolo e sfânta Cetate a Sucevei, scaunul domniei vechi cu ruinele măririi noastre, acolo scaunul firesc al unui mitropolit care în rang de neatârnare era egal cu patriarhii, acolo sunt moaştele celor mai mari dintre domnii români, acolo doarme Dragoş, îmblânzitorul de zimbri, acolo Alexandru întemeietorul de legi, acolo Ştefan, zidul de apărare al creştinătăţii. (...) Reținem două strofe din primul poem citat (Ştefan cel Mare, eboşă de poem, n.m.), atât pentru frumusețea evocării, cât şi pentru tăria de diamant a expresiei: Ce zgomot de bucium şi arme, ce val! / Când Ştefan se suie călare pe cal / Răspunde Suceava din urmă, / Şi nimeni nu ştie cum tu ai ajuns / Să ştii de ce munţii săgeată-ai pătruns - / Şia codrului cale se curmă. / Răsună pământul de tropotul des, / De-atâta oştire de munte, de şes, / Răspunde sunare de nouri; / Cu sunet de bucium la munte şi plai, / C-o oaste întreagă călare pe cai, / Cu steaguri cu semne de bouri. (Jucan, 1999, pp. 200-201)

[18]: Forma din colinde provine de la modul imperativ prezent al verbului care este valere!, adică "Fii sănător!", sau cu înțeles mai propriu vorbirii populare, "Să fii sănătos!", cum se urează frecvent în tradițiile de iarnă. (Cojocaru, 2001, 87-90)

[19] Nicolae Iorga. "XXXIV. Un cercetător al vieții poporului românesc. (Marian, 1994, 175)

[20] Din păcate, unele secvențe n-au fost suficient acoperite; la discipline (Etnojuridica, Etnomuzicologia, Medicina populară, Ştiința alimentației), concepte (Familie, Rudenie, Neam, Rasă), tehnici ale extazului şi ocultaţiei (magie, exorcism, sacru, profan) voi reveni. (Ursache, 2014, 8).

[21] LĂUTARII. Nunta e un act de bucurie şi veselie. Prin urmare, nu există nici o nuntă românească cel puțin în Bucovina, la care să nu fie şi lăutari (Lăutarii se mai numesc altmintrelea în Bucovina şi scripcari, de la scripcă, violină; apoi zicari - în ținutul Dornei-; în Transilvania, ceteraşi, de la ceteră, zicălaşi, de la a zice, a cânta). Excepție de la regula generală se face doar numai atunci, când unul dintre dânşii a mai fost odată căsătorit şi, prin urmare, nu vor să mai facă multă sfară în țară; aceştia fac nuntă tăcută, adică fără lăutari. De altmintrelea, fie fidenţaţii cât de sărmani, trebuie să aibă măcar câte o pereche de lăutari. Cel ce face nuntă fără 
lăutarinu e bine privit de consătenii săi, din contră, e ținut de om zgârcit, cărpănos şi morocănos, care nu voieşte ca şi alții să aibă parte de bucuria şi veelia lui. Despre astfel de oameni se şi zice apoi că nu fac nuntă, ci praznic. / Cum că lăutarii sunt uzitați nu numai la românii din Bucovina, ci pretutindeni, la toți românii, ne putem încredința, afară de experiența de toate zilele, încă şi dintr-o mulţime de balade, precum şi alte cântece poporane (T.T. Burada, O călătorie în Dobrogea, p. 178: Pe Stăncuţa mi-o lua / Lăutari el îşi tocmea / Mare nuntă mai făcea / Fericit cu ea trăia.), apoi şi din următoarele proverbe, care sunt foarte răspândite: Cu lăutari şi cu masă / Aduci pe dracu în casă. Sau: Cu lăuta şi cu toaba / Adusei în casă gloaba (A. Pann, op.cit., t. II, p. 111). / În Bucovina, e datină ca atât părinții miresei cât şi mirele să tocmească una sau mai multe părechi de lăutari. / Lăutarii tocmiţi de părinții miresei cântă numai la mireasă şi anume de sâmbătă sara, când se porneşte nunta şi până duminica sara, când pleacă mireasa de la părinții săi la casa mirelui. Ai mirelui însă cântă de sâmbătă sara şi până se sfârşeşte uncropul (paharul dulce şi ospăţul oferite de mire a oua zi după cununie, n.m.) şi nu numai la mire, ci şi la mireasă. Lăutarii mirelui trebuie să petreacă pe mire atât atunci când acesta se duce după mireasă, cât şi atunci când duce mireasa acasă şi să cânte tot timpul cât stă mirele la părinii miresei. (Marian, 2000, 165-166).

[22] Cu aparoția lăutarului, începe comercializarea şi decăderea cântecului tradițional. Se pierde din obişnuința cântecului ca dar (...) Se ştie că Mihai Viteazul s-a însoțit de muzicanți când a intrat triumfal în capitala tuturor românilor, Alba Iulia. Documentele depun mărturie pentru opt trâmbițaşi militari. Ei executau muzică ostăşească, de paradă. După o cunoscută informație a lui D. Cantemir, doina era adaptată la ritmuri avântate şi războinice. (Ursache, 2014.b, 54-55)

[23] S. Fl. Marian, Legende istorice din Bucovina, op. cit. ("Movila lui Răzvan", pp. 158-162, "Ştefan-Vodă", pp. 50-54, "Ştefan-Vodă şi turcii", pp. 55-64).

[24] Ibid.: "Dealul Leahului" (între Rădăuți şi Horodnicul de Jos, n.m.), pp. 153-154.

[25] Ibid.: "Cetatea Tătarilor", pp. 143-152, "Pietrele Muierilor", pp. 139-142, "Întemeierea Sucevei", pp. 6-10.

[26] Ibid.: "Românii şi tătarii", "Românca şi tătarii", "Dodul şi tătarii", "Găina şi Cucoşul", "Cetatea tătarilor", "Pietrele Doamnei", "Dragoş-Vodă", "Comoara îngropată" etc.

[27] Ibid.: "Ştefan-Vodă şi Tolpa", pp. 65-70.

[28] Ibid., "Dealul lui Ivan", pp. 178-179. 
[29] Ibid., "Comoara îngropată", pp. 47-49: "Multe şi mari neplăceri, neajunsuri şi daune au trebuit să sufere românii în timpurile trecute. Şi nici nu e mirare, după ce țările locuite de dânşii erau hăţaşul tuturor popoarelor barbare şi păgâne, care veneau din părțile răsăritului şi trecând ca nişte locuste hămisite printr-însele pe ce puneau mâna pus era. / Şi românii de multe ori, văzând că nu era alt chip de scăpare, luau tot ce aveau mai scump îb spate şi apucau drumul spre codru, unica lor mântuire la vreme de mare nevoie şi grea strâmtorare..."

[30] A mai vorbi despre însemnătatea literaturei poporane cred că, nu este de trebuință, căci în ziua de astăzi nu mai sta nimene la îndoelă cum că literatura modernă, trebue să se întemeeze pe cea poporană, scoțându-i la lumină si întrebuințându-i toate comorile cele mari, bogate şi frumoase ale literaturei poporane pentru redicarea edificiului literaturii moderne. Tote naţiunile, cari au o literatură au purces astfel şi de aceea au propaşit aşa de departe. Numai la noi acest adevăr abia târziu a izbutit a fi recunoscut; ... se începuse clădirea dela acoperiş în jos! Dar' în fine am ajuns şi noi la cunoscința adevărului, şi aceasta prin impulsul unui bărbat, care a scos la lumină o parte din comora nesecată a literaturei poporane şi ni-a zisu: Faceți întâi cunoştinţă cu traiul poporului, cu datinele lui, cu credințele lui şi mai ales cu limba lui cea dulce, frumoasă şi bogată, şi pe această temelie trainică zidiți monumentul literaturii naționale! Este oare de trebuință să mai zic cum că acest bărbat este Dl. V. Alecsandri?" (Marian, 1883, 3)

[31] Ioan Slavici, "Scrisoare către Simeon Florea Marian", în Simion Florea Marian şi corespondenţii săi, Ediţie îngrijită de Eugen Dimitriu şi Petru Froicu, Cuvânt înainte de Iordan Datcu, Seria "Documente literare", Editura Minerva, Bucureşti, 1991, pp. 340-341: "Sibiu, 9 aprilie 1884. Cristos a înviat, cucernice părinte, / Veți fi aflat de prin ziare că eu m-am însărcinat cu redacțiunea unui ziar quotidian ce se va înfiinţa aici de un consorțiu în care ne-am grupat tot oameni mai $m$ ult ori mai puțin independenți (...) Una dintre cele mai de căpetenie preocupări ale noastre e de a avea aici un centru de lucrare literară şi îndeosebi de a publica prin tipografia ce-am înființat-o cărți menite a deveni populare şi a răspândi astfel gustul de citire şi în general cultura în popor. / Mă simt dator a vă informa despre aceasta şi a vă ruga să vă uniţi cu noi în această lucrare. (...) / Vă rugăm totodată să binevoiți a ne trimite corespondența ori a vă pune în înțelegere cu alții, care-ar fi dispuşi să ne trimită, fie din Cernăuți, fie din alte părți ale Bucovinei. Prea mult ne-am bucura, dacă ni s-ar trimite şi ştiri mărunte despre evenimente de interes pentru publicul 
român, adunări, serbări publice, cazuri de moarte şi nenorociri, stări economice etc. (...) / Mulţămindu-vă de mai nainte pentru binevoitorul concurs şi felicitânduvă pentru premiul primit de la Academie, rămân al d-voastre devotat amic Ioan Slavici, Krantz-Gasse nr. 16". "Sibiu, 28 aprilie, 1884. Iubite amice, / Îți mulțumesc pentru scrisoare şi pentru concursul binevoitor ce-mi promiţi. Din "Ornitologie" poți să-mi trimiţi vreo 20 de exemplare deocamdată. Voi căuta eu să le vând. / Exemplare am trimis în Bucovina, nu mi-au venit însă până acum abonamente. Sper că ne vor veni pe viitor. De la mai mulți ni s-au înapoiat exemplarele. Astfel de la T. Stefanelli. Îi voi trimite lui anume din nou. (...)" (Slavici, 1991, 340-341)

[32] A se vedea şi Matei Udrea, "Ocărâtoarea" mită în istoria românilor": "Românii târâie de veacuri după ei tinicheaua obiceiurilor necinstite. Explicațiile acestor apucături - şocante pentru occidentali, îndrăgite de băştinaşi, generatoare de sărăcie şi nedreptate - trebuie căutate adânc în trecut, până la începuturile țărilor român.”/ „Nicio descriere nu se poate apropia de adevăr când este vorba să-i înfățişeze pe slujbaşii din Țara Românească. Nemăsurata lor imoralitate, ticăloşia acesta este cuvântul potrivit - îndurerează şi umple omenirea de silă." / Acesta este portretul funcționarilor din țările române făcut la începutul secolului al XIX-lea de Louis Langeron, nobil francez angajat ca ofițer în armata țarului pe parcursul războiului ruso-turc dintre 1806 şi 1812. De atunci au trecut 200 de ani, dar felul în care se comportă destui dintre administratorii statului român, de la clasa politică şi până la simpli funcţionari, poate da impresia că Langeron a trecut ieri prin România. (...) / În memoriile sale, contele francez Louis Langeron descoperea, acum 200 de ani, o explicație a mentalităţii locuitorilor de pe aceste meleaguri: „Mai înrâuriţi de către grecii din Fanar, căci un mare număr se află stabiliți la București, mulți boieri din Țara Românească au josnicia acestora, lăcomia lor, cruzimea lor şi, totodată, credinţa pe care o au ei faţă de turci“. Mărturia e importantă pentru că vine din partea unui străin care n-avea în comun cu românii decât faptul că ajunsese aici ca ofițer al unei armate de ocupație (cea rusească). / Jurnalul contelui, citat de Neagu Djuvara în „Între Orient şi Occident. T,ările române la începutul epocii moderne", e cutremurător. Langeron era complet bulversat de această lume pe care n-o înțelegea, aşa cum occidentalii nu reuşesc s-o înțeleagă nici acum. / „Cuvintele ordine, dreptate, cinste, onoare sunt adesea uitate în Țara Românească. Aici, toate slujbele se cumpără, adică se plăteşte dreptul de a săvârşi orice crimă fără a fi pedepsit. Fiecare slujbă, în scurt timp, îl îmbogățeşte pe cel care o cumpără, dar, 
după un an, trebuie s-o părăsească sau s-o lase altuia - căci încă un abuz al acestei cumplite cârmuiri (n.r. - fanariotă) este ca un slujbaş să nu stea niciodată mai mult de un an într-o slujbă, oricare ar fi ea; atunci vine la Bucureşti, unde se dedă unui lux neînfrânat şi de prost-gust, risipeşte la iuțeală rodul jafurilor sale şi, după doi ani de stat degeaba, mai cumpără o slujbă, se îmbogăţeşte din nou de pe urma ei, ca să vină iar în capitală şi să trăiască tot pe picior mare. Acesta este cercul vicios al boierilor din T, Tara Românească“, explica Langeron. / După cum se poate constata, într-o formă sau alta, sistemul s-a perpetuat până azi." (https://www.historia.ro/sectiune/general/articol/ocaratoarea-mita-in-istoriaromanilor, 11 noiembrie 2018)

[33] Cu toate acestea însă trebuie să însemnez că numirea de "pajură" se aplică de cătră poporul român mai mult numa pasărilor uriaşe şi năzdrăvane, pe care nu le cunoaşte din vedere, şi chipurilor acvilei de pe monede, pe când păsările cunoscute naturaliştilor sub numele de Aquillae, românii nu le numesc pajure, ci parte vulturi, parte cu alte numiri. / Cum că acest soi de păsări se numeşte de cătră români vulturi, ne putem încredința şi din următorul pasagiu, pe care-1 scoatem dintr-o poveste din România. (Marian, 1880, IV, 22, 347-351; Marian, 1880, IV, 23-24, 362-364)

[34] S.Fl. Marian, Ornitologia..., op.cit., Vol. I, p. 306, apud Basme cu animale și păsări, Ediție îngrijită şi prefață de Ligia-Bârgu-Georgescu, Ed. Minerva, Bucureşti, 1987, pp. 173-174.

[35] S. Fl. Marian, Ornitologia..., op.cit., Vol. I, p. 306, apud Basme..., op. cit., pp. 193-195.

[36] S. Fl. Marian, Ornitologia..., op.cit., Vol. I, p. 306, apud Basme.., op. cit., pp. 196-197.

[37] Valerius M. Ciucă, loc.cit, „Virtuţi şi vicii într-un libellus diffamatorius. Evoluţii juridice în serviciul onoarei. Excerptae”, în volumul colectiv Protecția datelor cu caracter personal, coordonatori: Irina Alexe, Dragoş-Nicolae Ploesteanu, DanielMihail Şandru, Editura Universitaria, Bucureşti, 2017.

[38] Vasile Alecsandri, Satire şi alte poetice compuneri de prinţul Antioh Cantemir (publicate în periodice).

[39] Bpesta, 3 dec. 1903. / Mult stimate domnule părinte, / Un grup de tineri călăuziți de dor de muncă am înfiinţat acum un an şi jumătate revista Luceafărul. Încurajaţi din toate părțile şi băgând de seamă că munca noastră e rodnică ne-am hotărât să mergem înainte, lucrând şi mai departe în vederea acluiaşi scop: propovăduirea gustului de-a ceti în publicul nostru şi educația literară-artistică a tinerei generații de la noi. / Credem că ne veți ierta pentru îndrăzneala noastră, rugându-vă să 
binevoiți a ne da şi d-voastră sprijinul moral. Am dori să avem în numărul prim, care se pune sub tipar la 15 dec. Nou, şi un articol mai scurt de d-voastră. (...) / Implinindu-ne rugarea de-ați face o mare bucurie şi ne-aţi deobliga foarte mult, mai cu seamă că şi pe st. Sfinţia-voastră vă leagă oarecari amintiri de origină de țara din care vine această respectuoasă rugăminte. / Primiți, vă rugăm, mulțumirile noastre anticipative şi încredințarea adâncei noastre stime. (Goga, 1903, dec. 3, 144-145) 